Halal tourism potential: an investigation in Bromo Tengger Indonesia 


\title{
HALAL TOURISM POTENTIAL: AN INVESTIGATION IN BROMO TENGGER INDONESIA
}

\section{POTENCIAL DE TURISMO HALAL: UNA INVESTIGACIÓN EN BROMO TENGGER INDONESIA}

\author{
Authors \\ Nikunlin Martaleni,Faculty of Economics and Business, Gajayana University, Malang \\ E-mail:martalenikulin65@gmail.com \\ Jose Rizal Joesoef,Faculty of Economics and Business, Gajayana University, Malang \\ E-mail:joserizalj@gmail.com \\ Gendut Budi Wahyono,Faculty of Economics and Business, Gajayana University, Malang \\ E-mail: budiwahyono@unigamalang.ac.id
}

Fecha de recibido: 15 de noviembre de 2019

Fecha de aceptado para publicación: 30 de noviembre de 2019

Fecha de publicación: 10 de diciembre de 2019

\begin{abstract}
The purpose of this research is to identify the potential of halal tourism destinations in Bromo Tengger by reviewing Attraction and Amenity variables. This research is a descriptive research with a quantitative approach. It used Primary data collection by using a questionnaire given to Moslem tourists aged 17 years old and they are originally from outside Bromo Tengger area. The sample of 250 was determined by sampling technique, which was then analysed in a descriptive and multivariate biplot exploratory analysis. The research findings show that amenity has quite big potential to support the realization of halal tourism in Bromo Tengger tourism destinations which is then followed by attraction variable. In general, it can be said that the brand building of Bromo Tengger's halal tourism destinations still requires greater assessment and efforts so that all indicators of halal tourist destinations can be fulfilled.
\end{abstract}

Keywords: amenities; attraction; Bromo Tengger; halal tourism.

El propósito de esta investigación es identificar el potencial de los destinos de turismo halal en Bromo Tengger mediante la revisión de las variables de atracción y amenidad. Esta investigación es una investigación descriptiva con un enfoque cuantitativo. Utilizó la recopilación de datos primarios mediante el uso de un cuestionario entregado a turistas musulmanes de 17 años de edad y que originalmente son de fuera del área de Bromo Tengger. La muestra de 250 se determinó mediante una técnica de muestreo, que luego se analizó en un análisis exploratorio biplot descriptivo y multivariado. Los resultados de la investigación muestran que las comodidades tienen un potencial bastante grande para apoyar la realización del turismo halal en los destinos turísticos de Bromo Tengger, que luego es seguido por la variable de atracción. En general, se puede decir que la construcción de la marca de los destinos turísticos halal de Bromo Tengger todavía requiere una mayor evaluación y esfuerzos para que se puedan cumplir todos los indicadores de los destinos turísticos halal.

Palabras clave: amenidades; atracción; Bromo Tengger; turismo halal. 


\section{Introduction}

Halal tourism has become a universal concept recently and is a niche market with potential to develop. Halal is an exclusive term in Islam which means permitted. No party can claim a halal product without obeying Islamic teaching. Halal and non-halal cover all spectrums of Moslem life, not only for food and beverages, but also for many things, including: tourism services, hotel services, banking services, travel agencies, and a sustainable environment (Baharuddin et al. 2015)

Halal tourism is one of the new tourism phenomena in halal industry (Samori et al. 2016; Fahim and Dooty, 2014; Bhuiyam, 2011) that respect principles, uphold culture and Islamic values (Namin, 2013; Kessler, 2015). Halal tourism is not an exclusive tourism product that will threaten other tourism industries, but it completes the existing tourism industries. Although halal tourism is an Islamic-based product, its existence is not only for Moslem tourists, but also for non-Moslem tourists (Chandra, 2014). So, non-Moslem tourists can also enjoy the norms of Moslems in traveling (Samori et al. 2016).

The opportunity for the development of halal tourism is a great chance and gives the rapid growth of the Moslem population in the world (Suid et al. 2017). In 2030, Moslem population is predicted to grow up by $26 \%$ of the world population (the Global Moslem Travel Index, hereinafter abbreviated as GMTI, 2016). With the increasing number of visits by Moslem communities, the demand for halal products will also increase naturally. Moslem tourists on their way pay attention to tourism attractions that do not conflict with Islamic teaching. (Afendi et al. 2014; Samsi et al. 2006; Battour et al. 2010). Therefore, the development needs for halal tourism is very high. However, halal tourism development and assessment have not shown a significant increase. Therefore, the presentation and description of halal tourism are very necessary in the world of tourism (Suherlan, 2015).

Indonesia is one of the countries that experienced a rapid increase in tourism after Bahrain, Saudi Arabia, the UAE and Egypt. Based on State of The Global Islamic Economic report in 2014-2015, Indonesia is the country with the largest Moslem population in the world. The report showed that tourist destinations in Indonesia, Bromo Tengger is one of the top ten priority tourist destinations in Indonesia to be developed between2016 - 2019. Bromo Tengger is a National Park in East Java, Indonesia, which has very beautiful and an atractive scenery for local and foreign tourists. The charming nature of sunrise or sunset panorama at Puncak Penanjakan makes this area very popular for many tourists. Bromo Tengger destinations are targeted to increase tourist arrivals from foreign countries such as Malaysia, Singapore, China, Japan, European countries and the Middle East region. Meanwhile, the domestic tourist may come from Java and Bali (Ratman, 2016).

From the target described earlier, the tourists from Malaysia and the Middle East region are dominantly Moslem. Thus, the tour packages of a tourist destination should be offered to meet the diverse of tourist's needs. Moslem tourists are more careful in using a product (goods or services), especially in considering that the product is halal or not. Therefore, the development of Bromo Tengger tourist destinations by offering halal tourism products cannot be ignored.

The development of halal tourism in Bromo Tengger will be interesting to be investigate $\mathrm{d}$ considering that there are different characteristics between prospective tourists 
and the majority of the population as well as tourism business around Bromo Tengger. As stated by the chief of the Tengger tribe, the majority $(80 \%)$ of the population around the Tengger Bromor area are Hindu. Meanwhile the majority of tourist targets are Moslems. The aim of identifying the potential of halal tourism in Bromo Tengger was done by reviewing Attraction and Amenity variables. This research is related to halal tourism marketing activities which can later be used as a basis for designing the right marketing strategy in order to increase the number of Moslem tourists in particular, both domestic and foreign tourists.

\section{Literature Review}

Tourism is a basic concept that covers a variety of behaviors in a social, economic, political, cultural and other environments and has an important role in the development of a country's economy (Namin, 2013; Martaleni, 2017). The concept of tourism consists of a range of activities, services, and benefits which all provide tourists with a particular experience (Nanim, 2013). In general the tourism industry has grown into a global activity that is quite vital in various countries in the world. This shows that the tourism sector today is very dynamic, always providing new business opportunities as well as a challenge to improve competitiveness through creative innovation in the tourism industry.

The phenomenon of Islamic economics today is an important part of the global economy. The development of business with a halal / sharia brand and service concept in each of its products has become a trend in the global economy. The concept of halal, in Arabic can be interpreted as "allowed" or permitted according to Islamic teachings (Wilson, 2014). Currently the concept of halal has been developed into various products, where the product can be termed using the word "sharia". These products include banking, hotel / lodging, insurance and tourism transactions, so the term Sharia Bank, Sharia Hotels / Lodging, Sharia Insurance and Sharia Tourism (halal tourism) emerged. Halal tourism, is one of the new tourism phenomena in the halal industry (Samori, Salleh and Khalid 2016; Fahim and Dooty, 2014; Chandra, 2014; Bhuiyam, 2011) that respect principles, uphold Islamic culture and values (Namin, 2013; Kessler, 2015) often referred to as Islamic tourism or Halal Tourism or Halal tourism or sharia tourism. Thus Battour and Ismail (2014) stated that halal tourism is "any tourist object or action that is permitted according to Islamic teachings to be used or involved by Moslems in the tourism industry". The definition considers Islamic teaching (sharia) as the basis for providing tourism products and services to the targeted customers who are mostly Moslem, such as halal hotels, halal restaurants, and halal trips. This can mean that halal tourism activities are not limited to the Moslem world, but include services and products designed for Moslem tourists in Moslem and non-Moslem countries.

The terminology of sharia tourism in some countries uses terms such as Islamic tourism, halal tourism, halal travel, or moslem friendly destinations (Dini et al. 2016). Sharia tourism is an activity supported by various facilities and services provided by the community, employers, government, and local governments that meet the requirements of Islamic teaching. Sharia tourism is used by many people because of the universal characteristics of its products and services. Tourist products and services, tourist objects, and tourist destinations in sharia tourism are the same as products, services, objects and tourism destinations in general as long as they do not conflict with Islamic values and ethics. Therefore, sharia tourism is not limited to religious tourism. 
In the Moslem society, morals are a standard of ethical quality in every action, which is characterized by Al-husn (good) versus Al-qubh (bad). This ethical quality is not what can be felt by human reason, but follows the commands of the Koran which they believes. Thus, all human actions are classified into five categories: as ordered, recommended, left unconcerned legally, understood, or prohibited. This is only the intermediate category (things that are legally indifferent) where there is scope for human legislation (Scott and Jafari, 2016). Furthermore, it is explained that Islamic doctrine determines what foods and beverages are legal or legal (permitted) and can be consumed by Moslems, how to dress, entertainment to be enjoyed, and how to live or behave.

Based on the above understanding, the concept of sharia which does not conflict with Islamic values and ethics is related to the halal and haram concepts in Islam. Halal is interpreted as permitted, while haram is interpreted as prohibited. The concept of halal can be viewed from two perspectives namely a religious perspective and an industrial perspective. What is meant by a religious perspective, namely as a law of what foods can be consumed by Moslem consumers according to their beliefs. This brings the consequence of consumer protection.

Halal tourism is a tourism industry that has contributed to economic growth in Indonesia, even though the world economy is slowing down. In Indonesia, halal tourism has long developed in the form of pilgrimages carried out by people with religious motivation. Along with global developments, this tourism experiences metamorphosis that requires modern changes ranging from attractions, hotels, to marketing. Through a phenomenological approach, it can be stated that halal tourism has become the part of national tourism industry to position Indonesia as the center of halal tourism in the world in the future (Jaelani, 2017).

Changes that occur require a deep agreement about the tourist's behavior in visiting a tourist destination. For example, tourist's behavior based on gender, Battour et al. (2010) found a difference between attitudes of female and male tourists to think over the tourist attributes when determining tourist destinations. Female tourists are more focused on privacy issues in crowd centers, while men are more at worship facilities and other halal facilities. In addition, the tourist motivation has a significant effect on overall tourist satisfaction (Martaleni, 2014). But Battour et al. (2010) stated that there is no significant relationship between motivation and satisfaction with moderated religion.

The rapid development of the Moslems population today is both an opportunity and a challenge for various industries whose target is the Moslem segment. There is a tendency for Moslems to change their tourism trips or destinations that are friendly to Islam, even if not to an Islamic country or a Moslem majority. Developing the tourism industry as halal tourism is an important need to encourage one's intention to travel. The factors driving the travel intention can play an important role to determine their attitude towards the destination. Attitude is also an important factor influencing the consumer intentions to buy halal products. People with a high positive attitude turned out to have a great intention to buy halal products (Afendi et al. 2014). Bozorgaghideh and Beegam (2015) in their research about Halal tourism in Kerala explained that Islam in Kerala is not an entrenched religion, but the Moslem population has grown rapidly in the world. For this reason, the target market is Moslem tourists, so the facilities that must be provided in tourist attractions is mosque facilities as a means of worship for Moslems (Kessler, 2015). India starts 
entering the beautiful and natural halal tourism market by ensuring that Moslem tourists can be served comfortably during their trip and able to do their religious obligations while on vacation.

From the research findings, it can be explained that with the rapid growth of Moslem population, it provides the opportunities for new market segments (Moslem markets) for countries that have tourist destinations. In the tour, the attributes of halal tourism have become a concern for Moslem tourists in choosing tourist destinations to be visited. Thus, the availability of halal tourist attributes has been able to become a motivation or basis for consideration of Moslem tourists to make a decision of tourist destinations which leads to tourist satisfaction.

\section{Methodology}

Descriptive research is employed in this study by using a quantitative approach. Malhotra (2007) stated that descriptive research aims to measure market characteristics or consumer perceptions. While quantitative research is an approach to test objective theory by testing the relationships between variables. These variables can be measured specifically on the instrument. Therefore, the numerical data can be analysed by statistical procedures (Creswell, 2014).

\section{Data Type}

The type of data in this research is qualitative data sourced from primary data. The primary data is obtained by conducting surveys and questionnaires. The questionnaire was designed by determining the information needed in this research. The information was obtained from the research of Dini et al. (2016); Samori et al. (2016); Widagdyo (2015); Battour and Ismail (2014) and based on the field. Next, the structure and layout of the questionnaire were made to be easily understood by the respondents and questionnaire trials were carried out before distributed to the respondents who were sampled.

The number of tourists visiting the Bromo Tengger destination area was recorded at 573,948 people in 2017 (Managing Center for Bromo Tengger Semeru National Park / TNBTS). The population used in this research was all Moslem tourists, both foreign and domestic tourists who visit Bromo Tengger destinations during the busy season (peak season) that is tourist's visits on national holidays, holidays, cancellations and new year's (low season) e.g. visits on effective days of school and work. The research population is scattered and it is difficult to know for sure. The sample collection is guided by the opinion of Sekaran and Bougie (2003) which suggests that the sample for descriptive research is at least 30 and a large sample of 500. Likewise Hair (2006) stated that the appropriate sample size is -200and here the sample used was 250. The determination of samples used in this research was judgment sampling techniques created by Malhotra (2007). The respondents are determined by the following criteria: (1) aged over or equal to 17 years; (2) Moslems; (3) originated from outside of Bromo Tengger.

\section{Research variable}

In this research, there are two measurements of variables, (1) Attraction, the main product from a destination that is a destination for tourist attractions such as natural tourism, cultural tourism and artificial tourism, and, (2) Amenity, all supporting facilities that can satisfy the needs and desires of tourists when traveling, including hotels and 
restaurants, travel agencies and guides. The assessments of each indicator on the variable using an ordinal scale which forms the basis of Likert scale at intervals strongly agrees (5) to strongly disagree (1).

\section{Data analysis}

Descriptive statistical analysis techniques are used to describe the characteristics of each respondent in the research. Moreover, to answer the objectives of the research, multivariate biplot descriptive and explorative analysis techniques are used by utilizing XLSTAT software. Information regarding biplot display are follows:

1. The closeness between objects is used to see the similarity of characteristics between objects. Two objects with the same characteristics are described as two points with adjacent positions.

2. The diversity of variables is used to see if there are variables with almost the same diversity for each object. The variables with small diversity are described as short vectors, while variables with large diversity are described as long vectors.

3. Correlation between variables aims to determine the effect of one variable to another variable. Two variables that have a positive correlation value will be described as two lines in the same direction or forming sharp angles. Conversely, two variables with negative correlations are described as two lines with opposite directions or forming blunt angles. Two uncorrelated variables are represented in two directed lines with an angle close to 90 .

4. Value variables on an object aim to see the superiority of each object. The object that is located in the direction of the variable vector is said that the object has a value above the average. However, if the object is located in the opposite direction to the direction of the variable vector it is said that the object has a value below the average. The object that is close in the middle means that it has a value close to the average.

\section{Result}

\section{Respondent Profile}

The data obtained directly from respondents by using questionnaires are 325. About 275 respondents filled it completely, and 250 exemplar of questionnaires were taken and they were filled in completely or in accordance to the number of research samples for further process. The identity of the respondent includes age, occupation and domicile. The distribution of male and female respondents was relatively balanced, $52 \%$ female respondents and 48 male respondents. The majority of respondents work in the private sector $(31 \%)$ followed as students $(29 \%), 15 \%$ civil servants, $11 \%$ self-employed, $7 \%$ students and the remaining 7\% work in other sectors. Most respondents aged 17-23 years (39\%), followed by ages 24-30 years (29\%), 31-36 years (15\%), 37-43 years $(8 \%)$ and respondents aged over 43 years ( $9 \%$ ). The highest percentage of respondents visiting Bromo Tengger destinations came from East Java (69\%), followed by West Java (16\%), Jakarta (7\%), outside of Java such as Sumatra, Kalimantan, Sulawesi, Bali and so on (4\%), Central Java (3\%) and overseas (1\%). According to the data, it can be interpreted that the sample data can represent the populations in terms of gender, occupation, age, nationality, and domicile. 


\section{Descriptive Analysis}

The following explained how the tourists responded to each variable and indicator on each variable which was carried out by filling out questionnaires with a range of values based on a 1 - 5 Likert scale with order 1 means strongly disagree while 5 means strongly agree.

Table 1: Average Value of Each Indicator

\begin{tabular}{|c|c|c|}
\hline No. & Variable & Average \\
\hline \multicolumn{3}{|c|}{ A. $\quad$ Variabel Atraksi : natural, cultural and artificial tourist attraction } \\
\hline 1 & Have natural attractions, cultural tours and interesting artificial tours & 4.200 \\
\hline 2 & Halal food and baverages are available & 4,052 \\
\hline 3 & Present cultural arts performances that do not conflict with Islamic teaching & 3.548 \\
\hline 4 & Environment and sanitation in Bromo tourist destinations are kept clean & 3.360 \\
\hline 5 & A mosque having sufficient water supply is available & 3,300 \\
\hline \multicolumn{3}{|c|}{ B. Amenity variable : hotel and restaurant } \\
\hline 6 & There are food and beverages that are guaranteed halal. & 3,844 \\
\hline 7 & A decent place for purification is available & 3,756 \\
\hline 8 & Clean environment & 3,756 \\
\hline 9 & Mosque facilities are available equipped with Qibla directions & 3,708 \\
\hline \multicolumn{3}{|c|}{ C. Amenity variable : tourist tour bureau } \\
\hline 10 & Provide halal tourism packages & 3,760 \\
\hline 11 & Have a list of halal tourism accommodations & 3,720 \\
\hline 12 & Has a list of halal food and beverage providers & 3,716 \\
\hline \multicolumn{3}{|c|}{ D. Amenity variable : tourist guide } \\
\hline 13 & The guides serve in such communicative, friendly, honest and responsible way & 3,840 \\
\hline 14 & The guides carry out Islamic values in carrying out their duties & 3,704 \\
\hline 15 & The guides have competence in accordance to their profession. & 3,696 \\
\hline 16 & The guides wear clothes that are in accordance to Islamic teaching & 3,580 \\
\hline
\end{tabular}

Table 1 describes the first indicator of attraction variable about Bromo tourist destinations which has attractive natural, cultural, and artificial tourist attractions with an average value of 4,200 having the highest response, followed by Bromo tourist destinations presenting cultural arts performances that do not conflict with Shari'a Islam $(3,548)$, environment and sanitation in Bromo tourism destinations are kept clean $(3,360)$ and the Bromo tourist destination environment provides Mosque that has sufficient amount of water supply $(3,300)$. Bromo tourist destinations have interesting natural, cultural and artificial tourist attractions to develop, considering that it has natural attractions with the presence of Mount Bromol with its beautiful sunrise views. To enjoy this phenomenon, the tourists must go up to Penanjakan Peak which is famously known as the best spot to see the sunrise. Fatigue caused of climbing will be paid off by a magnificent sunrise panorama. 
When the sun slowly crawls up, the atmosphere will be very calm and only the sound of a tourist camera's shots is heard, as shown in the following picture.



Figure 1 - Bromo Tourist Object

Amenity variable with its sub variables like Hotels and Restaurants were measured by four indicators, they are the availability of halal food and beverages, the availability of decent place for purification, the availability of mosque facilities equipped with Qibla direction, and the availability of clean environment. In table 1, it can be seen that the indicators of Hotels and Restaurants concerning on the availability of halal food and beverages get the highest response with a value of 3.844. It can be signified that Hotels and Restaurants in the Bromo Tengger destination providing the halal food and beverages are well rated by tourists. Then it is followed by the maintenance of environmental cleanliness, the availability of a proper place for cleaning and the availability of mosque facilities equipped with Qibla directions. Hotels and restaurants in the Bromo Tengger destination mostly serve halal food and beverages for tourists who come. Hotels and restaurants are well aware that tourists visiting are mostly Moslem tourists who are very careful in deciding what they will consume.

Sub variable of Travel Bureau was measured by three indicators; providing halal tour packages, providing a list of halal tourist accommodations and having a list of halal food and beverage providers. After calculating the average value as shown in Table 1, it shows that the highest response is in first indicator, the travel agency provides travel packages for halal tourism. It indicates to go to the Bromo Tengger tourist destination, a Travel Bureau that offers halal tourism packages is got good rate by tourists. The travel agency of Bromo Tengger tourist destination has provided halal tour packages, a list of halal tourist accommodations and a list of halal food and beverage. Meanwhile, Travel Bureau which has a list of halal tourism accommodations and a list of halal food and beverages is considered lower rate.

Based on Figure 2, the highest response is on indicator 3, the guides serve the costumers communicatively, friendly, honest and responsible. Whereas the lowest indicator is that the guides wear clothes that are accordance with Islamic teaching. The tour guide who serves tourists in the Bromo Tengger destination communicatively, kindly, honestly 
and responsibly is also appraised by tourists. The ways of guides carrying out their duties and guides by implementing Islamic values have been considered to be quite good rate.

To see the magnitude response, the rate of visitors in Bromo Tengger tourist destinations on the variables and sub variables is studied, the total average value of each variable and sub-variance obtained as shown in Figure 2 is obtained.

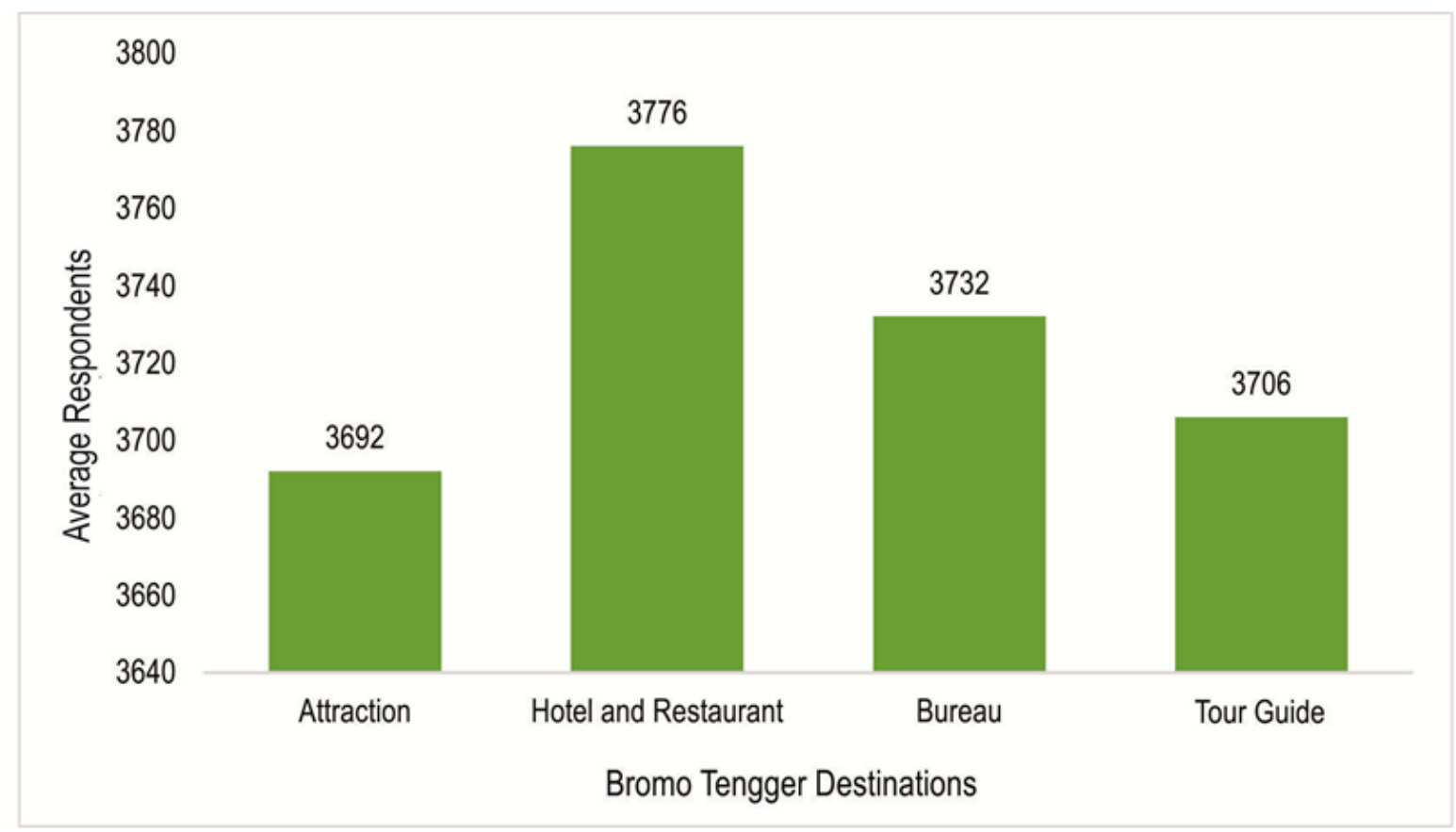

Figure 2 - the variable average score of Respondent's Response

The Figure 1 shows that overall rate, the highest response of visitors in Bromo Tengger's halal tourism is the Hotel and Amenities Restaurant variable with a value of 3,766 , followed by the Travel Bureau $(3,732)$, Guide $(3,706)$ and the lowest in the Attraction variable $(3,692)$. The Amenity variable with the highest response is given to the availability of halal food and beverages provided byte Hotels and Restaurants, the availability of decent place for purification, the availability of Mosque facilities equipped with qibla directions and clean-up is a potential as halal tourism variable, added by the Bureau Travel trips and guides. Moreover, the attractions that consist of natural attractions, cultural tourism and interesting artificial tourism, presenting cultural arts performances that do not conflict with Islamic teaching, the availability of clean environment and sanitation in Bromo tourism destinations, the availability of a mushola having sufficient amount of water supply, and the availability of Halal food and beverages is considered to have the lowest value. Thus, the variable of halal tourism that can be developed more is on the amenity aspect.

\section{Bi-plot analysis}

To see the suitability of the model used, first the Eigen values were calculated. The value of the suitability was described based on the respondents' age (93.25\%) (Figure 3), 
followed by respondents occupation (94.25) (Figure 4) and respondents' domicile (93.45) (Figure 5) on the two components of the first and second factors. This value is quite high, so the biplot results obtained are very representative and can be interpreted further.

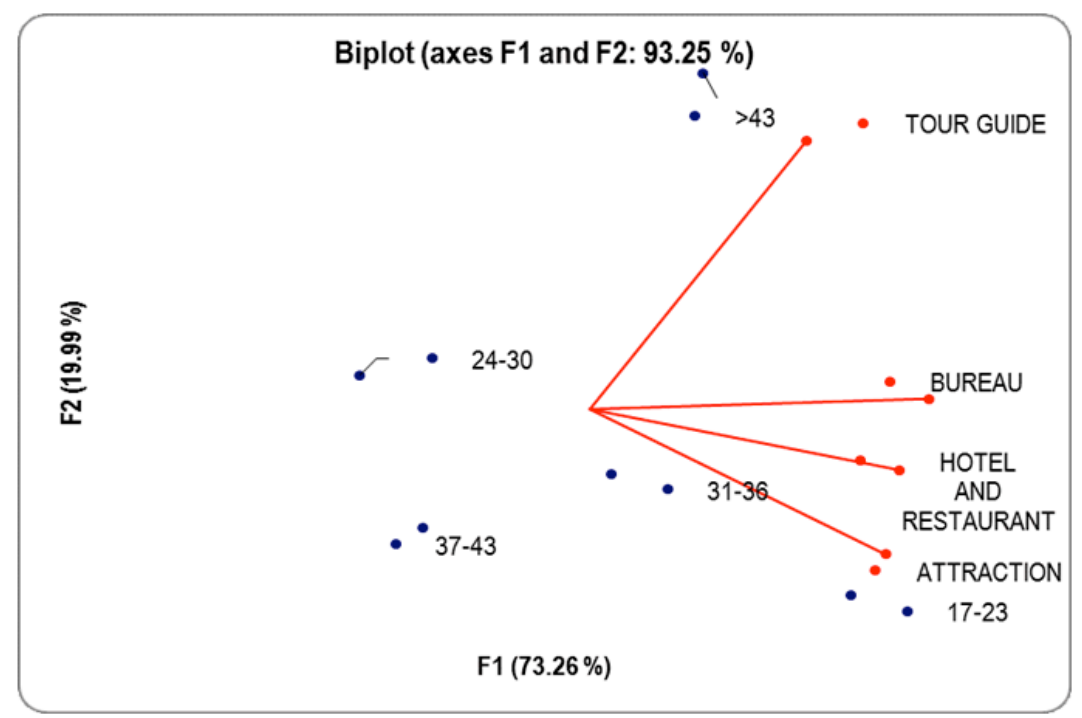

Figure 3 - Biplot Object based on age

Based on the vector length formed on Figure 3, the Travel Bureau variable has the highest diversity followed by Guides, Attractions and Hotels and Restaurants. High diversity indicates that the response on the importance of the Travel Bureau is relatively more diverse among respondents while the responses to the Hotels and Restaurants tend to be the same or stable. From the grouping of respondents formed, the respondents tended to spread and did not make special groups. The groups of respondents aged 17-23 years and 31-36 years tended to attach on the importance of attractions while groups of respondents aged over 43 years were more concerned with guides. Other age groups, 24-30 years and 37-43 years, did not attach on the importance to the four variables studied because the distance was relatively far from the existing variable vectors.

In the Figure 4 is obtained some information that tour guides and travel agents have very strong and positive correlation or relationship (almost perfect, from the point of view that is very coherent).on the other hand, the travel Agency shows that the relationship between hotel and restaurant variables and attractions is negative as indicated by conflicting vectors, as well as the relationship between the variables of the Travel Bureau and Guides to Hotels and Restaurants and Attractions. If the response of the Hotel and Restaurant is considered as the important factor, the Attraction becomes unimportant and vice versa. And if the response of the Tour Guide and Travel Bureau is also reckoned as the major factor, the Attraction and Amenity will be insignificant and vice versa.

According to the length of the vector formed, the variable of Travel Bureau and Guide has the highest diversity followed by Hotels and Restaurants and Attractions. High diversity indicates that the response on the importance of Travel Agencies and Guides is relatively diverse among respondents. While the responses to Attractions tend to be the 
same or stable. From the grouping of respondents' occupation, the respondents who work as civil servants in private sector and students tend to form one group and have a very positive response to the variables of Travel Agencies and Guides. Therefore, if people want to target market segmentation in this work group, the Bromo Tengger party can improve halal tourism services in the aspect of Travel Agencies and Guides. On the other hand, the respondents with entrepreneurial work has very positive response to the Attraction variable. The student respondents tend to give low responses to all aspects. The respondents with other occupations are more concerned with the Attractions aspect than the other variables.

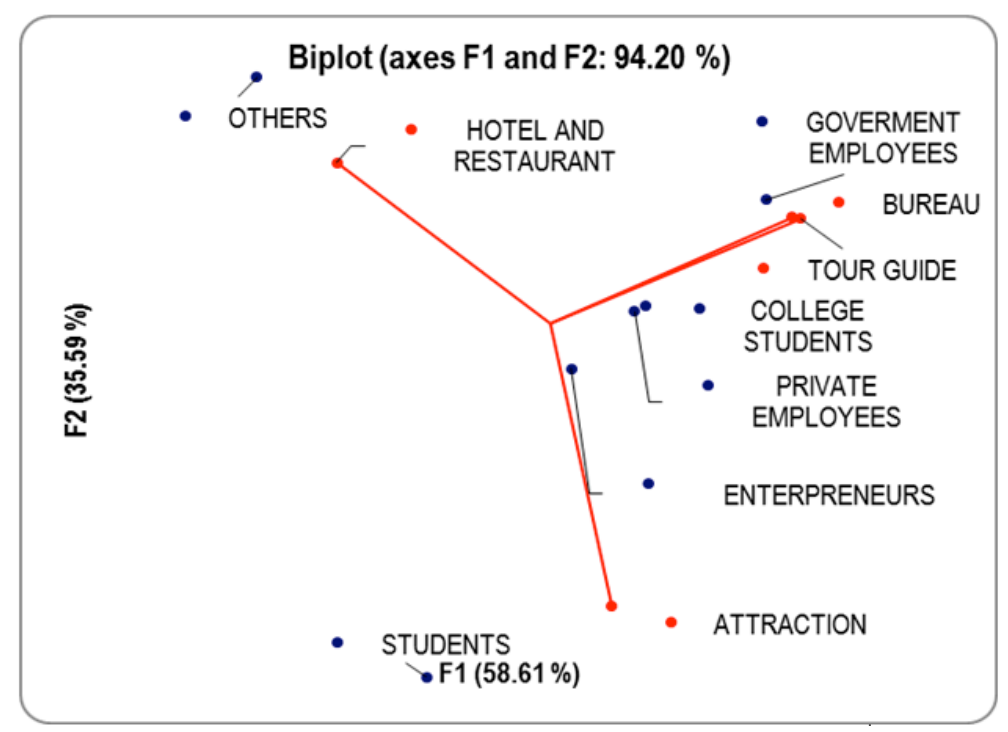

Figure 4 - Biplot object based on respondent's occupation

From Figure 5, the biplot mapping on respondent objects based on domicile provides information that the four attractions variables, guides, travel agencies and hotels have a positive correlation, where the respondents are equally concerned with the four aspects. The correlation between attractions to guides is much tighter than to hotels and restaurants because of the vector position that is much closer to the tour guide. The length of the vector formed shows that the tour guide variable has the highest diversity followed by Travel Agencies, Attractions and finally Hotels and Restaurants. High diversity indicates that the response to the importance of guides is more diverse among respondents relatively although the responses to attractions tend to be the same or stable. 


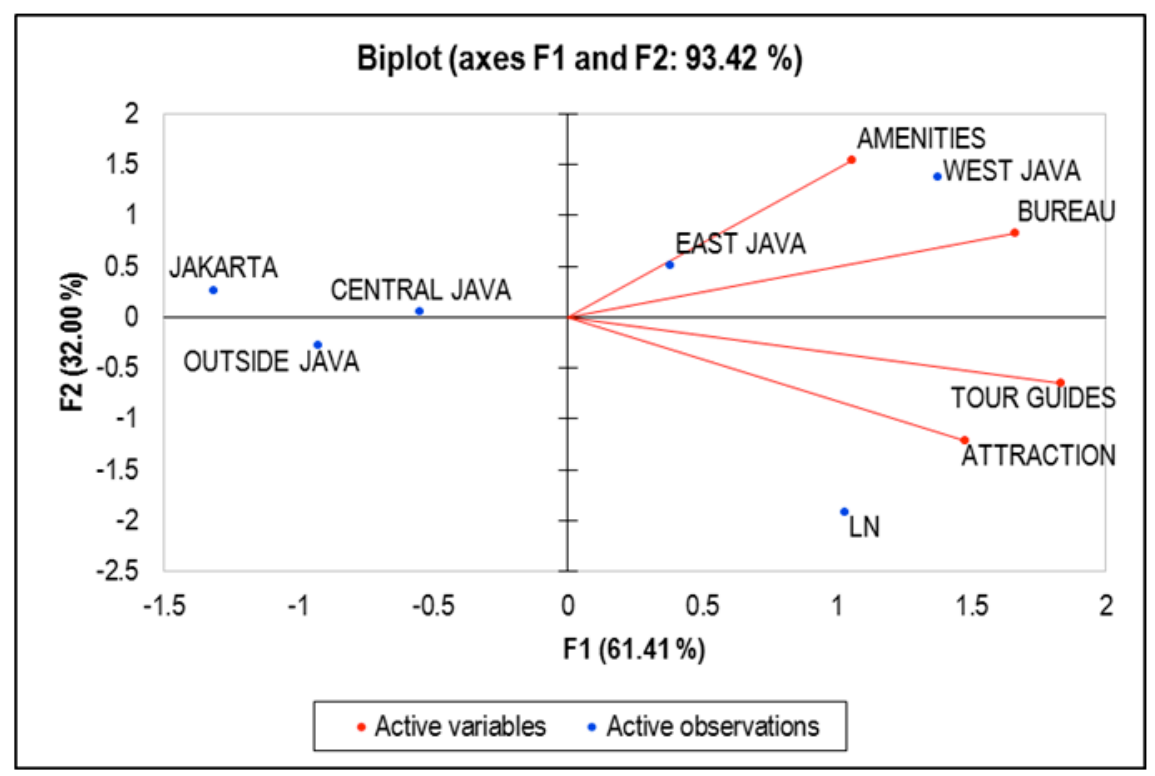

Figure 5 - Biplot object bases on domiciles

\section{Discussion}

Based on the results of research, the average response of tourists to aspects of halal tourism in Bromo Tengger tourist destinations, it can be concluded that the Amenity variable shown by the availability of Hotels and Restaurants gets the best response compared to travel agencies, tourism guides and attractions. This means that the most potential aspects to be developed toward the potential of halal tourist destinations in Bromo Tengger are the aspects of Hotels and Restaurants. This facts are proven by the availability of hotels / restaurants that provide halal food and beverages, the availability of sanctuaries, the availability of mosques, qibla directions and the cleanliness of their environment. This will make Moslem tourists in particular comfortable to enjoy the food and beverages at the hotel / restaurant (Karim et al. 2017). Moreover, it provides a suitable place to cleanse oneself for praying (Battaour et al. 2010). Besides, it also provides a complete mosque with guidance on qibla (Battor et al. 2010) and a clean environment. Mosques are an important feature in tourist attractions especially for Moslem tourists. Mosques are also a place to seek for knowledge for both Moslems and non-Moslems (Kessler, 2015).

The second halal tourism potential is in the aspect of the travel agency to travel in Bromo Tengger tourist destinations. The evidence is shown by the travel agency efforts starting from the availability of list of halal tourism accommodations and a list of halal food and beverages in response to good tourists. The information of halal food and beverages is needed by tourists because it will make tourism trips comfortable (Karim et al. 2017). Even non-Moslem tourists are aware of the existence of halal food and halal principles (Golnaz et al. 2010). Several services provided by travel agents as halal tour packages for the tourists are considered the best choice. Tourist destinations need to do and maintain a good relation with the Travel Bureau to accommodate the sales promotion (Widagdyo, 2015).

Similarly, the tourist guide is considered as the third aspect of halal tourism potential at the Bromo Tengger destination. This is believed to be able to carry out the Islamic 
values, good competence, serve communicatively, friendly, honestly, and responsibly and they also wear clothing encouraged by Islamic teaching. The tourists guide serves the tourists in communicative manner, friendly, honest and responsible way and this is included as the indicator obtaining the best response. Serving tourists in a friendly and communicative manner will provide tourists' satisfaction (Tan et al. 2017). In general, Islamic attributes on tourist destinations and tourist satisfaction have significant impact on loyalty (Rahman, 2014; Bazazo and Elyas, 2017). Ensuring the availability of Islamic attributes in destinations and services can lead to obtain the tourists' satisfaction and inspire them to return (Suid et al. 2017). Consumer loyalty is also seen as important part to achieve the success of an organization's business because attracting new consumers is further more expensive than maintaining existing ones (Donio et al. 2006; Kotler and Keller, 2014).

Furthermore, the attraction aspect is halal tourism potential which has the lowest value in this research. Attractions are indicated by indicators of Bromo Tengger tourist destinations that have natural, cultural, and artificial interesting tourist attractions and the availability of halal food and beverages served by the hotel and restaurants tend to be relished better. The next, it is followed by Bromo Tengger tourist destinations which present cultural art performances that do not conflict with Islamic teaching, the good maintenance of environment, good sanitation, and the availability of ablutions with sufficient water. The availability of a clean environment is important to attract the tourists (Tan et al, 2017).

The fact on the data collection showed the groups of tourists aged 17-23 years and 3136 years tend to prioritize attractions. Whereas the groups of tourists aged over 43 years prioritized guides. The other age groups, 24-30 years and 37-43 years, did not prioritize the four variables studied. This means that the differences in age groups of tourists also change the way they view the tourist attractions visited. In other words, it can be said that different age segments concern with different needs priority. As a manager of a tourism business, the design of marketing strategies is necessary to pay attention to the variety of services needed and desired by each group of tourists based on their characteristics. The characteristics of tourists will influence the characteristics of their trips (Phosikham et al. 2015).

Tourists who work as Civil Servants (PNS), Private and Students tend to form one group and have a very positive response to travel agencies and guides. On the other hand, tourists with entrepreneurial work have a very positive response to Attractions. The tourists who work as students tend to give low responses to all aspects. The Tourists with other works are more concerned with the Attractions aspect than the other variables. This explains that tourists who work as civil servants, private employees and students are a market segment paying more attention to the aspects of travel agencies that are used to go to tourist destinations and services provided by guides. The travellers who have status as entrepreneurs prioritize the aspects of attractions especially in natural tourism, cultural tourism and artificial tourism on their visits. Meanwhile, the tourists with the status of students do not prioritize these two aspects (amenities and attractions). Therefore, if you want to target market segmentation in a segment based on profession, as the manager of Bromo Tengger or businessman must be able to improve halal tourism services in the aspects of the Travel Agency, tour services and attractions that are more attractive.

In the different variable, the domicile grouping of tourists, the tourists from East Java and West Java are more concerned with the Amenities of the Hotels and Restaurants than 
other variables. Foreign tourists prioritized more in attractions and the tourists from Central Java, Jakarta and Outer Java regions did not prioritize the four aspects studied. The indication showed that the tourists from East Java and West Java prioritize the aspect of hotels that provide halal food and beverages, and also the availability of mosques. The tourists from abroad prioritized the attractions including natural tourism, cultural tourism and artificial tourism. The tourists from Central Java, Jakarta and outside Java prioritize all aspects of halal tourism including attractions (natural tourism, cultural tourism and artificial tourism), hotels and restaurants, travel agencies and guides. The tourists who come from different regional groups tended to have different priority scales in their tourist visits. So if you want to target the market segment of groups from East Java and West Java, then the manager of Bromo Tengger can improve halal tourism services in the Amenities aspects of hotels and restaurants that provide halal food and beverages, and halal Travel Bureau.

Based on these findings, we concludes that the Bromo Tengger tourist destination is in accordance to predetermine the destination criteria, so it can make Bromo Tengger tourist destinations to be a friendly destination for Moslem tourists or halal tourist destinations. Halal tourism is a new phenomenon that has emerged from the growth of the halal industry (Samori et al. 2016) or a new business that can be started to meet the unique needs of Moslem tourists when they are away from home (Pungniyom et al. 2017). The fulfilment of tourists' needs for Moslem by providing facilities with a halal concept will be able to grant the tourists' satisfaction (Putit et al. 2016). However, this depends on the management or relevant agencies to expand the market share by targeting the Moslem segment or tourists who tend to consider selected tourist attractions as Moslem-friendly tourist destinations. Managerial expertise is needed to adapt the ethnic or religious attributes. The development of tourism products, innovation, transformation and marketing also have important role in advancing tourism destinations with the Islamic approach. Fulfilling the expectations of Islamic tourists are done not only by satisfying the tourists' desired experience, but also protecting the values and quality of life that exist in tourist destinations (Namin, 2013).

\section{Conclusions}

Based on the results of the research and discussion described earlier, we can conclude that descriptive analysis of the aspect of amenity has big potential to support the realization of halal tourism in Bromo Tengger tourist destinations rather than attractions aspect. This is indicated through the comfort felling by tourists towards halal food and beverages, the availability of a sanctuary, the availability of mosques with qibla direction and a clean environment when conducting tourist visits.

From the data in age group of tourists on the potential aspects of amenities and attractions show that tourists aged 17-36 years tend to provide an assessment that attraction variable has the potential to support the realization of halal tourism. While tourists over the age of 43 provides a strong assessment on Guides. The other age groups, 24-30 years and 37-43 years indicate that the four variables studied have not shown great potential in realizing halal tourism destinations in Bromo Tengger. In the aspects of employment (professions), the tourists who work as civil servants, private sector and students give positive assessment on the variable amenities that are the most potential support in halal tourism in Bromo Tengger tourist destinations. Meanwhile, the tourists who work as entrepreneurs consider that the aspect of attractions is the most potential in supporting halal 
tourism in Bromo Tengger tourist destinations by tourists and. but the tourists with student professions consider that Bromo Tengger tourist destinations haves low potential to become halal tourist destinations in aspect of attractions. The last, the region of origin / domicile of tourists or domestic tourists think that amenities variable has more potential to support halal tourism, whereas the foreign tourists perceive that attractions variables are more potential.

In general, I states that the halal concept in Bromo Tengger tourist destinations is completely new, so it needs more in-depth and specific research and exploration. Therefore, to build branding of Bromo Tengger's halal tourist destinations, it still requires greater assessment and efforts so that all indicators of halal tourist destinations can be fulfilled.

\section{Limitations}

This research has not been able to reveal detailed empirical data from the surrounding community about halal tourism potential considering the halal concept is a new concept for them.

\section{Practical implications}

The findings of this research are very important for tourism businesses and local and central governments in managing tourism business that is able to answer the needs of tourists and increase the number of tourist visits such as the tourist needs for the availability of hotels and restaurants that provide halal food and beverages and the availability of mosques that have clean environments.

\section{Social Implications}

I also suggested that business actors must be able to design the right marketing strategy to satisfy the needs of the target market, especially Moslem tourists. Society or business people must be able to understand the behavior of Moslem tourists in using any product more carefully by paying attention to halal or non-halal. Through, the fulfillment of the needs or satisfaction of tourists in Bromo Tengger tourist destinations, it is expected that the number of tourist visits will increase continually which will lead to an increase in the welfare of the surrounding community.

\section{References}

Afendi, Noor A., Farah L. Azizan, Aflah I. Darami. 2015. Determinants of Halal Purchase Intention; Case in Perlis. International Journal of Business and Social Research 4(5): 118-123.

Baharuddin, Kasmarini, Norliya A. Kassim, Siti K. Nordin, and Siti Zahrah Buyong 2015. Understanding the Halal Concept and the Importance of Information on Halal Food Business Needed by Potential Malaysian Entrepreneurs. International Journal of Academic Research in Business and Social Sciences 2(5): 170-180.

Battour, Mohammed M., Mohd N. Ismail, and Moustafa Battor. 2010. The Impact of Destination Attributes on Muslim Tourist's Choice. International Journal of Tourism Research 13(6): 527-40.

Battour, Mohammed M., and Mohd N. Ismail. 2014. The Role of Destination Attributes in Islamic Tourism. SHS Web of Conferences 12, 1-8. 
Bazazo, Ibrahim, and Tariq Elyas. 2017. The Impact of Islamic Attributes of Destination on Destination Loyalty via the Mediating Effect of Tourist Satisfaction. International Journal of Business Administration 8(4): 65-78.

Bhuiyam, Md. Anowar H, Siwar Chamhuri, Shaharuddin M. Ismail, and Rabiul Islam. 2014. Potentials of Islamic Tourism: A Case Research of Malaysia on East Coast Economic Region. Australian Journal of Basic and Applied Sciences 5(6): 13331340 .

Bozorgaghideh, Nargeskhatoon, and Resia Beegam. 2015. Halal Tourism in Kerala. International Journal of Management 6: 42-48.

Chandra, Geetanji R. 2014. Halal tourism; Anew Goldmine for Tourism. International Journal of Business 4(6): 45-62.

Creswell, John W. 2014. Research Design: Qualitative, Quantitative, and Mixed Methods Approaches. Fourth Edition. SAGE Publications, Inc.

Donio, Jean, Paola Massari, and Giuseppina Passiante. 2016. Customer Satisfaction and Loyalty in a Digital Environment: an Empirical Test. Journal of Consumer Marketing 23(7): 445-457.

Dini, Andriani, Akbar Kemal, and Titi Nurhayati. 2016. Laporan Akhir Kajian Pengembangan Wisata Syariah. Deputi Bidang Pengembangan Kelembagaan Kepariwisataan.

Fahim, Syeda T., and Evana N. Dooty. 2014. Islamic Tourism: In the Perspective of Bangladesh. Global Journal of Management and Business Research 14(1): 1-7.

Golnaz, Rezai, Zainalabidin Mohamed, Mad N. Shamsudin, Eddie F. C. Chiew. 2010. NonMuslims' awareness of Halal principles and related food products in Malaysia. International Food Research Journal 17(3): 667-674.

Hair, Joseph F. 2006. Multivariate Data Analysis. Pearson Education International.

Jaelani, Aan. 2017. Halal Tourism Industry in Indonesia: Potential and Prospects. International Review of management and Marketing 7(3): 25-34.

Karim, Mohd Hyrul A., Rozila Ahmad, and Noor Azimin Zainol. 2017. Differences in Hotel Attribtes: Islamic Hotel and Sharia Copleant Hotel In Malaysia. Journal of Global Business and Social Entrepreunership (GBSE) 1(2): 157-168.

Kessler, Kristel. 2015. Conseptualizing Mosque Tourism: a central fiture of Islamic and religious tourism. International Journal of Religious Tourism, 3(2): 11-32.

Kotler, Philip, and Kevin Lane Keller. 2014. Marketing Management. Pearson Education, Inc.

Malhotra, Naresh K. 2007. Marketing Research an Applied Orientation. Pearson International Edition.

Martaleni. 2014. Pengaruh Motivasi, Kualitan Layanan, dan Kepuasan wisatawan Terhadap Image Daerah Tujuan Wisata. EKUITAS Jurnal Ekonomi dan Keuangan 18(2): 20118.

Martaleni. 2017. Pemasaran Pariwisata Indonesia. CV. IRDH (Research \& Publishing). 
Namin, A.A. Tajzadeh. 2013. Value Creation in Tourism: An Islamic Approach. International Research Journal of Applied and Basic Sciences 4(0): 1252-64.

Phosikham, Thongmala, Anoulom Vilayphone, and Sengdeuane Wayakone. 2015. The Relationships between International Tourists' Travel Characteristics, Their Sources of Information, and Their Level of Satisfaction Based On Socio-Demographics, In Luang Prabang Province, Lao PDR. International Journal of Business and Social Science 6(11): 47-61.

Puangniyom, Piyachat, Nantawan Swangcheng, and Tosaporn Mahamud. 2017. Halal Tourism Strategy to Promote Sustainable Culture Tourism in Thailand. Paper presented at the International conference on studies in Arta, Social Science and Humanities, January 26-27, in Cebu. Philippines.

Putit, Lennora, Mazzini Muda, Ainul N. Mahmood, Nor Z. Ahmad Taufek, and Norhayati Wahib. 2016. Liking Halal Friendly Hotel Attributes and Customer Satisfaction: The Islamic Tourism Sector. Journal of Emerging Economic and Islamic Research 4:4353.

Rahman, Muhammad K. 2014. Motivating Factor of Islamic Tourist's Destination Loyalty: An Empirical Investigation in Malaysia. Journal of Tourism and Hospitality Management 2(1): 63-77.

Ratman, Dadang R. 2016. Pengembangan Destinasi Pariwisata Prioritas 2016-2019. Paper Presented at Ministry of Tourism National Coordination Meeting: Acceleration of Tourism Development in Order to Achieve the Target of 12 Million Foreign Tourists and 260 Million National Travelers, Januari $27^{\text {th }} 2016$, in Jakarta, Indonesia.

Samori, Zakiah, Nor Z. M. Salleh, and Mohammad M.Khalida. 2016. Current Trends on Halal Tourism: Case on Selected Asian Country. Tourists Management Perspective 19: $131-136$.

Samsi, Siti Zakiah BT. M., Hamsida Jamaluddin, Azleen Shabrina, Mohd Noor, Siti N. H. Mohd, and Saleha Abdullah. 2016. Information Quality, Usefulness and Information Satisfaction in Islamic E-Tourism Websites. Journal of Theoretical and Applied Information Technology 89(2): 450-60.

Scott, Noel, and Jafar Jafari. 2016. Moslem world and its tourisms. Annals of Tourism Research, 44: 1-19.

Sekaran, Uma, and Roger Bougie. 2003. Research Methods for Business: A Skill- Building Approach. John Wiley \& Sons, Inc.

Suherlan, Ade. 2015. Persepsi Masyarakat Jakarta Terhadap Islamic Tourism. The Journal of Tauhidinomics 1(1): 61-72.

Suid, Intan S., Nor A. M. Nor, and Hamimi Omar. 2017. A Review on Islamic Tourism and Pratical of Islamic Attributes of Destination in Tourism Business. International Journal Research in Social Scinces 7(12): 255-269.

Tan, Chuie-Hong, Xin-Wei Chong, and Gowrie Vinayan. 2017. Perceived Quality of Visit and Foreign Tourists Satisfaction in Malaysia. International Journal of management and Applied Science 3(2): 61-65. 
Widagdyo, Kurniawan G. 2015. Analisis Pariwisata Halal di Indonesia. The Journal of Tauhidinomics 1(1), 73-80.

Wilson, Jonathan A.J. 2014. The Halal Phenomenon: An Extension or a New Paradigm?. Social Business 4(3): 255-271. 